\title{
LANDASAN FONDASIONAL INTEGRASI KEILMUAN DI UIN MAULANA MALIK IBRAHIM MALANG DAN UIN SUNAN AMPEL SURABAYA
}

\author{
Husniyatus Salamah Zainiyati \\ Universitas Islam Negeri Sunan Ampel Surabaya, Indonesia \\ E-mail: husniyatus@yahoo.com
}

\begin{abstract}
This article deals with the foundational base for integration of sciences trough interdisciplinary Islamic studies, with particular reference to UIN Malang and Surabaya. There are eleven IAINs/STAINs which have been transformed into UIN, each university has their own concept of developing Islamic knowledge. UIN Malang has the concept of pohon ilmu (the tree of sciences) and UIN Surabaya has the concept of integrated twin towers with three pillars. Although different in developing the concept, the two universities share the same perspective of perceiving the relation between general and religious sciences. The integration of science does not refer to the classification of its subject, but rather to the object of knowledge so that religious values can be transformed into different disciplines. It is hoped that in the long term UIN-with the foundation of the Qur'ân and Hadîth-can motivate the emergence of new sciences as blessing for the universe, or at least give new alternatives for the existing sciences, such as Islamic economics. The integration of sciences also needs to be articulated in learning models which are developed while emphasizing harmony between the intellectual tradition of higher education and local tradition of pesantrens.
\end{abstract}

Keywords: The tree of sciences; integrated twin towers; integration of sciences.

\section{Pendahuluan}

Dewasa ini masih muncul anggapan sebagian besar masyarakat bahwa "agama" dan "ilmu" merupakan dua entitas yang berbeda dan tidak bisa diintegrasikan karena keduanya memiliki zona yang khas, baik dari segi objek formal-material, metode penelitian, kriteria kebenaran, peran yang dimainkan oleh ilmuwan maupun status teori masing-masing, bahkan sampai pada penyelenggaraan institusinya. 
Menurut M. Amin Abdullah, sejarah kependidikan Islam terbelah menjadi dua wajah, yaitu paradigma integralistik-ensiklopedik dan paradigma spesifik-paternalistik. Paradigma pengembangan keilmuan yang integralistik-ensiklopedik dipelopori oleh ilmuwan Muslim, seperti Ibn Sînâ, Ibn Rushd, Ibn Khaldûn, sedangkan ahli Hadîth dan ahli fiqh mewakili pengembangan keilmuan yang bersifat spesifikpaternalistik. Keterpisahan secara diametral (dikotomis) antara keduanya atau sebab lain yang bersifat politis ekonomis berakibat pada rendahnya kualitas pendidikan dan kemunduran dunia Islam saat itu. Oleh karena itu, Abdullah menawarkan gerakan rapproachment (gerakan untuk saling menerima keberadaan yang lain dengan lapang dada) antara kubu keilmuan yang dianggap sebagai sebuah keniscayaan. Gerakan ini disebut dengan reintegrasi epistemologi. ${ }^{1}$

Meski demikian, beberapa pemikir Islam seperti al-Kindî, Ibn Sînâ, Ibn Rushd, dan lainnya pada saat itu tidak menunjukkan perbedaan dalam pembidangan disiplin ilmu. Para sejarawan lebih melihat kemajuan ilmu pengetahuan dan teknologi pada zaman keemasan Islam adalah bentuk harmonisasi nilai-nilai agama Islam yang bersumber pada wahyu terintegrasi dengan ilmu pengetahuan dan teknologi sehingga menjadi produk peradaban manusia. Hal inilah yang menjadi pijakan mendasar mengapa struktur keilmuan di Universitas Islam Negeri (UIN) perlu mempertimbangkan kelebihan dan kekhususan pengintegrasian nilai-nilai agama Islam dengan ilmuilmu lainnya. ${ }^{2}$

Dikarenakan pesatnya perkembangan ilmu pengetahuan serta semakin berkembangnya studi keislaman di era globalisasi, maka fungsi dan mutu pendidikan tinggi menjadi hal penting untuk dikembangkan. Dengan kata lain, pengintegrasian ilmu agama dan ilmu umum dalam bingkai kurikulum UIN tidak hanya menjadi suatu kebutuhan melainkan juga keniscayaan.

\section{Landasan Yuridis-Teologis Integrasi Ilmu Agama dan Umum}

Secara yuridis, pengembangan keilmuan UIN didasarkan pada ketentuan, antara lain: pertama, Undang-undang Nomor 20 Tahun

1 M. Amin Abdullah, "UIN: Menuju Integrasi Ilmu dan Agama" dalam M. Zainuddin (ed.), Memadu Sains dan Agama Menuju Universitas Islam Masa Depan (Malang: Bayumedia Publishing, 2004), 5.

2 Rachmat Syafei, "Integrasi Ilmu Agama dalam Sistem Kurikulum UIN" dalam Nanat Fatah Natsir (ed.), Pandangan Keilmuan UIN Wabyu Memandu Ilmu (Bandung: Gunung Jati Press, 2008), 242. 
2003 tentang Sistem Pendidikan Nasional. Pasal tiga yang menjelaskan bahwa Pendidikan Nasional berfungsi mengembangkan kemampuan dan membentuk watak serta peradaban bangsa yang bermartabat dalam rangka mencerdaskan kehidupan bangsa, bertujuan untuk mengembangkan potensi peserta didik agar menjadi manusia yang beriman dan bertaqwa kepada Tuhan Yang Maha Esa, berakhlak mulia, sehat, berilmu, cakap, kreatif, mandiri dan menjadi warga negara yang demokratis dan bertanggung jawab. Selanjutnya pada pasal 36 ayat tiga disebutkan bahwa kurikulum disusun sesuai dengan jenjang pendidikan dalam kerangka Kesatuan Negara Republik Indonesia yang memperhatihan aspek peningkatan iman dan takwa, peningkatan akhlak mulia, peningkatan potensi, kecerdasan dan minat peserta didik, keragaman potensi daerah dan lingkungan, tuntutan pembangunan daerah nasional, tuntutan dunia kerja, perkembangan ilmu pengetahuan, teknologi dan seni, agama, dinamika perkembangan global serta persatuan nasional dan nilai-nilai kebangsaan. Sedangkan dalam pasal 38 ayat tiga disebutkan kurikulum pendidikan tinggi dikembangkan oleh perguruan tinggi yang bersangkutan dengan mengacu pada standar nasional pendidikan untuk setiap program studi.

Kedua, Kepmendiknas RI No. 232/U/2000 tentang Pedoman Penyusunan Kurikulum Pendidikan Tinggi dan Penilaian Hasil Belajar Mahasiswa. Pemerintah, dalam hal ini Mendiknas memberi keleluasaan kepada pengelola lembaga pendidikan tinggi untuk mengembangkan kurikulum mereka sendiri. Pemerintah hanya memberikan rambu-rambu bagi pedoman pengembangnnya.

Secara teologis, integrasi ilmu agama dan ilmu umum ini didasarkan kepada QS. al-Mujâdilah [58]: 11:

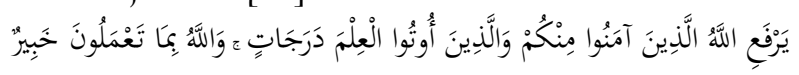

"Allah mengangkat derajat orang-orang di antara kamu yaitu mereka yang beriman dan diberi ilmu pengetahuan, dan Allah Maha Mengetahui apa yang kamu kerjakan”.

Mengapa orang yang beriman dan memiliki ilmu pengetahuan secara komprehensif akan dihormati atau diberi kepercayaan dibandingkan dengan orang yang tidak memiliki ilmu pengetahuan? Ini artinya orang beriman dan berilmu lebih tinggi dibandingkan dengan orang yang tidak berilmu. Meski demikian, orang beriman tetapi tidak berilmu juga akan lemah. Karena itulah, keimanan seseorang yang tidak didasari dengan ilmu pengetahuan tidak akan 
kuat. Pun sebaliknya, orang yang berilmu tapi tidak beriman juga akan tersesat.

Berdasarkan penjelasan tersebut, secara normatif Islam tidak mengenal dikotomi ilmu. Makna integratif di sini adalah keterpaduan kebenaran wahyu dengan bukti-bukti yang ditemukan di alam semesta. Struktur keilmuan yang integratif di sini tidak berarti antara berbagai ilmu tersebut dilebur menjadi satu bentuk ilmu yang identik, melainkan karakter, corak, dan hakikat antara ilmu tersebut terpadu dalam kesatuan dimensi material-spiritual, akal-wahyu, ilmu umumilmu agama.

\section{Landasan Filosofis Integrasi Ilmu Agama dan Ilmu Umum}

Dalam perspektif keilmuan Islam, posisi filsafat Islam merupakan landasan adanya integrasi berbagai disiplin keilmuan. Dalam konstruk epistemologi Islam, filsafat Islam dengan metode rasionaltransendentalnya dapat menjadi dasarnya. Misalnya, fiqh pada hakikatnya adalah pemahaman yang dasarnya adalah filsafat, kemudian juga dikembangkan dalam ushul fiqh. Tanpa filsafat, fiqh akan kehilangan semangat inovasi, dinamisasi dan perubahan. Oleh karena itu, jika terjadi pertentangan antara figh dan filsafat, maka hal ini disebabkan terjadinya kesalahpahaman dalam memahami risalah kenabian.

Menurut al-Kindî—yang dikutip oleh Harun Nasution-agama dan filsafat adalah dua hal yang berbeda baik dari aspek sumber maupun metodenya. Agama berasal dari wahyu Tuhan, sedangkan filsafat berasal dari pengetahuan diskursif manusia. Meski demikian, tujuan tertinggi (ultimate goal) yang ingin dicapai keduanya adalah kebenaran pertama dalam persoalan ketuhanan atau metafisika, sehingga tujuan agama dan filsafat adalah sama. Dengan demikian, alKindî mempertemukan agama dan filsafat pada bentuk substansinya, pada kajian puncaknya yakni kebenaran tertinggi atau kebenaran tunggal yang sama-sama dicari oleh filsafat dan agama. ${ }^{3}$

Para ilmuwan dahulu memang mengklasifikasikan ilmu dalam berbagai macam, misalnya al-Fârâbî membagi ilmu menjadi beberapa kategori, antara lain: ilmu bahasa, logika, matematika, dan ilmu masyarakat dengan masing-masing cabangnya. Ibn Khaldûn membuat klasifikasi ilmu menjadi dua yaitu naqlîyah dan 'aqlîyah. Ilmu naqlîyah adalah ilmu yang berdasarkan wahyu, yang termasuk dalam Ilmu

${ }^{3}$ Harun Nasution, Filsafat dan Mistisisme dalam Islam (Jakarta: Bulan Bintang, 1978), $15-16$. 
naqlîyah yaitu al-Qur'ân, Ḥadîth, fiqh, kalam, tasawuf dan bahasa. Sedangkan ilmu 'aqliyah adalah ilmu yang berdasarkan rasio, yang termasuk ilmu 'aqliyah yaitu filsafat, kedokteran, pertanian, astronomi, dan sebagainya. Sedangkan al-Ghazâlî membagi ilmu menjadi keilmuan agama (shar'yyah) dan keilmuan non-agama (ghayr alshar'îyah). Kedua ilmu tersebut oleh al-Ghazâlî diberi status yang sama yaitu fardu, harus ditempuh dan dimiliki oleh umat Islam. Menurut Azyumardi Azra klasifikasi ilmu tersebut bukan dimaksud mendikotomi ilmu antara satu dengan yang lain, tetapi hanya sekadar klasifikasi. Klasifikasi tersebut menunjukkan bahwa ilmu tersebut telah berkembang dalam peradaban Islam. Dalam konteks ini, ilmu agama Islam merupakan salah satu saja dari berbagai cabang ilmu secara keseluruhan. ${ }^{4}$

Ahmad Tafsir-dengan merujuk pada Ibn Khaldûn-mengatakan bahwa klasifikasi pengetahuan dibagi kepada pengetahuan yang diwahyukan (naqlìyah) atau dalam istilah konferensi ilmu di Makkah disebut dengan perrenial dan pengetahuan yang diperoleh ('aqlîah) atau acquired. Tafsir juga menekankan pengintegrasian kedua pengetahuan itu harus dimulai dengan membangun kembali filsafat pengetahuan dalam Islam, dan juga mengintegrasikan sistem pendidikan. Orang Islam harus segera menyadari bahwa tradisi aslinya telah dikacaukan oleh tradisi Barat yang memang memisahkan pengetahuan yang diwahyukan dari pengetahuan yang diperoleh. ${ }^{5}$

Al-Faruqi menjelaskan bahwa akibat dari paradigma sekuler Barat, pengetahuan modern menjadi kering, bahkan terpisah sama sekali dari tauhid. Sebagai prasarat untuk menghilangkan dualisme sistem pendidikan, pengetahuan harus "diislamkan". Islamisasi pengetahuan harus memperhatikan sejumlah prinsip yang merupakan esensi Islam, yang mencakup lima kesatuan, yaitu kesatuan Tuhan, kesatuan alam, kesatuan kebenaran, kesatuan hidup dan kesatuan umat Islam. ${ }^{6}$ Lebih jelasnya, pengetahuan modern telah lepas atau melepaskan diri dari nilai-nilai teologis.

\footnotetext{
${ }^{4}$ Azyumardi Azra, Pendidikan Islam: Tradisi dan Modernisasi Menuju Milenium Baru (Jakarta: Logos Wacana Ilmu, 1999), xii-xiv.

5 Ahmad Tafsir, Metodologi Pengajaran Agama Islam (Bandung: Remaja Rosdakarya, 1997), 18.

6 Isma'il Raji al-Faruqi, Islamisasi Pengetahuan, terj. Anas Mahyudin (Bandung: Pustaka, 1984), 55-96.
} 
Dengan demikian, persoalannya bukan "ilmu agama" dan "nonagama", tetapi lebih kepada "kepentingan", untuk apa ilmu tersebut digunakan, karena ilmu merupakan instrumen, bukan tujuan. Apalagi jika kita sepakat bahwa pada dasarnya sumber ilmu itu dari Allah. Seperti dijelaskan oleh Tafsir bahwa pada saat ilmuwan Muslim mengembangkan ilmu pada masa awal, "ilmu agama" atau "ilmu keagamaan" dan "ilmu umum" tidak terpisah melainkan terintegrasi secara sempurna. Pada waktu itu, tidak ada dikotomi antara keduanya seperti yang kita kenal sekarang.

Pada waktu itu, ilmuwan Muslim merasa wajib "membaca" (iqra). Artinya, wajib belajar dan meneliti. Tuhan menyuruh manusia belajar dengan menggunakan ungkapan iqra'. Tuhan juga menyediakan dua sumber belajar, yaitu al-Qur'ân dan al-kawn (alam semesta). Kemudian sumber itu menjadi tempat manusia menimba pengetahuan. Manusia meng-iqra' kedua sumber tersebut.

Tafsir mengungkapkan bahwa dari kegiatan iqra' tersebut terhimpunlah pengetahuan. Mereka mempelajari al-Qur'ân dan dari situ muncul tiga jenis pengetahuan. Pembagian ilmu pengetahuan menjadi tiga dengan paradigma, objek, metode dan kriteria tersendiri dapat disederhanakan dalam tabel berikut: ${ }^{7}$

Tabel 1

Pengetahuan Manusia

\begin{tabular}{|l|l|l|l|l|}
\hline Pengetahuan & Paradigma & Objek & Metode & Kriteria \\
\hline Sains & Sains & Empirik & Sains & $\begin{array}{l}\text { Rasional- } \\
\text { Empirik }\end{array}$ \\
\hline Filsafat & Rasional & $\begin{array}{l}\text { Abstrak- } \\
\text { Rasional }\end{array}$ & Rasional & Rasional \\
\hline Mistik & Suprarasional & $\begin{array}{l}\text { Abstrak- } \\
\text { Suprarasional }\end{array}$ & $\begin{array}{l}\text { Latihan, } \\
\text { Percaya }\end{array}$ & $\begin{array}{l}\text { Yakin, } \\
\text { kadang- } \\
\text { kadang } \\
\text { Empiris }\end{array}$ \\
\hline
\end{tabular}

Berdasarkan tabel tersebut, sains adalah pengetahuan yang diperoleh dengan menggunakan paradigma sains (scientific paradigm). Pengetauan ini hanya mengambil objek-objek empiris untuk ditelitinya. Objek-objek yang tidak empiris tidak dijadikan objek penelitiannya. Dalam meneliti, sains menggunakan metode ilmiah

7 Ahmad Tafsir, Filsafat Pendidikan Islam: Integrasi Jasmani, Rohani, dan Kalbu Memanusiakan Manusia (Bandung: Remaja Rosdakarya, 2010), 105-107. 
(scientific method) yang bekerja atas dasar paradigma Logico-Hypothetico$V$ erificatif. Temuannya dikatakan benar apabila ia bersifat rasional dan empiris yang disebut dengan pengetahuan ilmiah atau pengetahuan ilmu (scientific knowledge) dalam bahasa Inggris disebut science.

Adapun filsafat (philosophical knowledge, rational knowledge) adalah pengetahuan yang diperoleh dengan menggunakan paradigma rasional (rational paradigm). Pengetahuan jenis ini diperlukan untuk ragam objek yang tidak dapat diteliti secara ilmiah karena objek itu abstrak tetapi masih dapat dipahami rasio. Metode penelitian yang digunakan dalam pengetahuan filsafat adalah metode rasional, sedangkan benar tidaknya temuan dibuktikan atas dasar rasional atau tidak.

Pengetahuan mistis adalah jenis pengetahuan dengan menggunakan paradigma suprarasional atau boleh disebut metarasional. Objek yang diteliti adalah sisa objek pengetahuan sains dan pengetahuan filsafat, jadi objek yang diteliti adalah ragam objek yang tidak empiris dan tidak rasional. Ragam objek seperti itu disebut dengan objek metarasional atau suprarasional. Untuk memperoleh jenis pengetahuan jenis ini kita dapat menggunakan metode iman. Artinya, kita hanya mengimaninya saja, dengan syarat karena ada alasan-alasan logis. Terkadang metode latihan dapat digunakan untuk memperoleh pengetahuan jenis ini. Misalnya, untuk memperoleh pengetahuan yang bersifat peyingkapan (kashf) metode latihan tidak dapat terhindarkan. Metode latihan itulah yang dalam dunia tasawuf sering disebut metode riyâdah. Benar tidaknya temuan ditentukan oleh keyakinan kita seperti kesimpulan kita tentang adanya surga dan neraka; kadang-kadang kebenaran temuan dapat dibuktikan secara empiris seperti pada kasus pelet, debus, dan sebagainya. Bedanya dengan kebenaran sains adalah bahwa pengetahuan mistik terkadang mempunyai bukti empiris tetapi tetap tidak rasional.

Berkaitan dengan hal tersebut, al-Qur'ân-yang berisi sekumpulan pengetahuan Tuhan-ditulis dalam bahasa Arab. Ilmuwan Muslim memperoleh pengetahuan dengan cara menafsirkan ayat-ayat alQur'ân tersebut. Al-Kawn juga berisi kumpulan pengetahuan Tuhan, dalam bentuk alam semesta. Ilmuwan Muslim memperoleh pengetahuan dengan cara mempelajari dan meneliti gejala-gejala hukum alam tadi pada alam. Ilmuwan Muslim dapat memperoleh pengetahuan dari mempelajari al-Qur'ân, yang bentuknya dapat dikatakan teori; dari mempelajari al-Kawn ilmuwan Muslim memperoleh pengetahuan, bentuknya juga dapat disebut teori. Teori- 
teori yang didapat dari mempelajari al-Qur'ân tidak mungkin berlawanan dengan teori-teori yang didapat dari mempelajari al-Kawn sebab dua kelompok teori itu adalah teosentris, karena tidak ada perlawanan dalam pengetahuan Tuhan. Jadi, pengetahuan sains, pengetahuan filsafat, dan pengetahuan mistik yang diambil dari alQur'ân tidak mungkin berlawanan dengan pengetahuan yang diambil dari al-Kawn karena ia sama berasal dari dan dibuat oleh Tuhan. Uraian di atas dapat dilihat pada gambar sebagai berikut: ${ }^{8}$

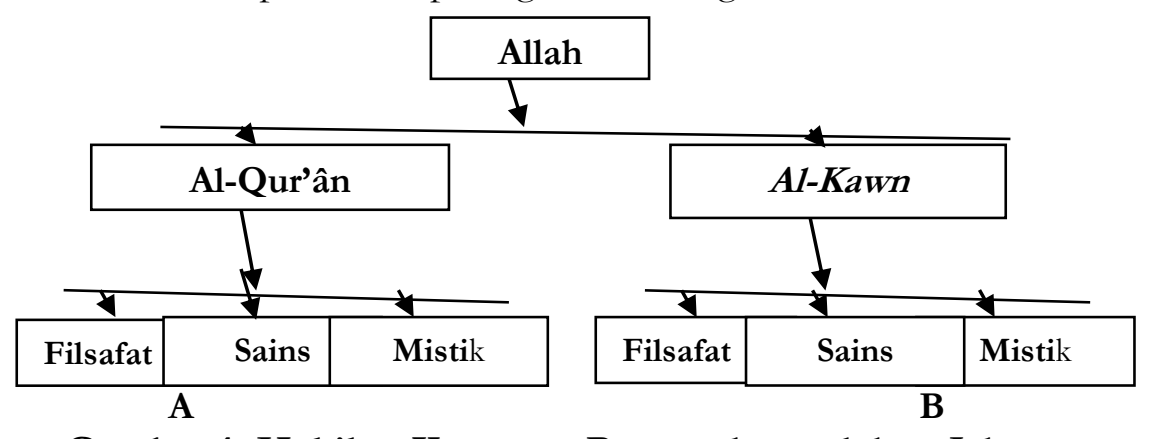

Gambar 1. Hakikat Kesatuan Pengetahuan dalam Islam

Berdasarkan gambar tersebut, teori-teori pada bagian A tidak akan berlawanan dengan teori-teori pada bagian B. Inilah hakikat kesatuan pengetahuan dalam Islam. Al-Qur'ân sebagai sumber ilmu pengetahuan dan pengetahuan spiritual, menurut Oesman Bakar, merupakan basis bukan hanya bagi agama dan pengetahuan spritual tetapi bagi semua jenis pengetahuan. Gagasan keterpaduan ini merupakan konsekuensi dari gagasan keterpaduan dari semua jenis pengetahuan. Al-Qur'ân bukanlah kitab sains, tetapi ia memberikan pengetahuan tentang prinsip-prinsip sains yang selalu dikaitkannya dengan pengetahuan metafisik dan spiritual. Oleh karena itu, sains Islam mempunyai karakter religius dan spritual. Menurut Ibn Sînâ, sebuah sains disebut sains yang sejati jika ia menghubungkan pengetahuan tentang dunia dengan pengetahuan tentang prinsip Ilahi. ${ }^{9}$

Adapun alam merupakan sumber berbagai jenis pengetahuan: matematika, fisika, dan metafisika; ilmiah dan spiritual; kualitatif dan

\footnotetext{
8 Ibid., 111-112.

9 Oesman Bakar, Taubid dan Sains: Perspektif Islam tentang Agama dan Sains, terj. Yuliani Liputo dan M. S. Nasrulloh (Bandung: Pustaka Hidayah, 2008), 149-156. Dalam hal ini, Oesman Bakar juga menunjukkan bahwa terdapat banyak ilmuwan dan risalah dalam Islam yang membuktikan kebenaran kesatuan pengetahuan ilmiah dan spiritual, misalnya di wilayah zoologi oleh al-Jâhiz dalam bukunya The Book of Animals abad kesembilan.
} 
kuantitatif; praktis dan estetis. Hal ini karena, sebagai sebuah dunia dan dipandang dalam totalitasnya, realitas alam semesta mencakup berbagai macam aspek. Setiap jenis pengetahuan bersesuaian dengan aspek alam tertentu untuk dikaji secara terpisah.

Dalam Islam, kesatuan alam semesta dipandang sebagai citra kesatuan prinsip ilahi. Tujuan sains Islam adalah untuk memperlihatkan kesatuan alam semesta dan kesalingterhubungan seluruh bagian dan aspeknya. Alam dipandang sebagai wahyu Ilahi, sebanding dengan al-Qur'ân. Ia menyampaikan pada manusia pesan metafisik dan spiritual dari yang Transenden. Dalam konsepsi religius dan spiritual tentang alam inilah terdapat basis bagi kesatuan sains dan pengetahuan spiritual. ${ }^{10}$

Senada dengan penjelasan Bakar dan Tafsir, Endang Saifuddin Anshari menjelaskan bahwa mustahil terjadi pertentangan antara agama Islam dengan ilmu pengetahuan atau filsafat yang benar. Sebab ilmu atau filsafat yang benar adalah hasil usaha manusia dalam memahami kenyataan alam; susunan alam; pembagian alam. AlQur'ân atau ayat Qur'anîyah tidak lain adalah pembukuan segenap alam semesta atau ayat Kawnyyah dalam satu al-Kitâb. Kedua ayat Allah tersebut saling menafsirkan. ${ }^{11}$ Karena itulah, perbedaan formulasi antara ilmu yang satu dengan ilmu yang lain tentang suatu masalah tertentu adalah lazim dalam dunia ilmu pengetahuan. Dengan demikian terminologi "ilmu agama" dan "ilmu umum", "non-agama" adalah peristilahan sehari-hari dalam pengertian sempit saja.

\section{Pemaknaan Integrasi Ilmu dan Agama}

Integrasi berasal dari bahasa Inggris integration yang berarti kesempurnaan atau keseluruhan. Poerwadarminto mengartikan integrasi adalah penyatuan supaya menjadi suatu kebulatan atau menjadi utuh. ${ }^{12}$ Dalam ilmu sosial, integrasi dimaknai sebagai proses penyesuaian di antara unsur-unsur yang saling berbeda dalam kehidupan masyarakat sehingga menghasilkan pola kehidupan masyarakat yang memiliki keserasian fungsi. ${ }^{13}$ Misalnya integrasi orang

\footnotetext{
${ }^{10}$ Ibid., 151.

11 Endang Saifuddin Anshari, Ilmu, Filsafat dan Agama (Surabaya: Bina Ilmu, 1987), 176.

12 W.Y.S. Poerwadarminto, Konsorsium Bahasa Indonesia (Jakarta: Balai Pustaka, 1986), 384.

13 Dalam hal ini, bentuk integrasi sosial ada dua, yaitu assimilasi dan akulturasi. Assimilasi adalah pembauran kebudayaan yang disertai dengan hilangnya ciri khas kebudayaan asli, contoh etnis keturunan Tionghoa yang berada di Indonesia.
} 
Cina ke dalam tubuh bangsa Indonesia tanpa kehilangan identitas dan tata kehidupannya yang serba eksklusif, dan mereka merupakan suku baru yang setingkat dengan suku Jawa, Sunda, Batak, dan sebagainya. ${ }^{14}$ Integrasi dapat terjadi pada bidang politik, budaya, maupun pendidikan.

Pertanyaannya kemudian adalah apa yang dimaksud dengan integrasi ilmu dan agama? Bagaimana caranya? Apakah dengan memadukan antara ilmu agama dan umum seperti yang terjadi di lingkungan pendidikan Islam saat ini? Atau dengan cara membekali calon sarjana dengan pemahaman norma-norma keagamaan?

Sebagaimana diketahui, kebanyakan lembaga pendidikan Islam, mulai Madrasah Ibtidaiyah (MI) sampai Perguruan Tinggi Agama Islam (PTAI) memang memberikan materi-materi ilmu keagamaan seperti tafsir, Hadîth, fiqh, dan lainnya, dan pada waktu yang sama juga memberikan berbagai disiplin ilmu modern yang diadopsi dari Barat. Maksudnya, mereka telah melakukan integrasi ilmu dan agama, memang benar. Akan tetapi, integrasi yang dilakukan tersebut biasanya hanya sekadar memberikan ilmu agama dan umum secara bersama-sama tanpa dikaitkan satu sama lain, apalagi dilakukan atas dasar filosofis yang mapan.

Di beberapa pesantren mahasiswa juga dilakukan integrasi. Di pesantren-pesantren tersebut, para santri yang mayoritas mahasiswa digembleng dengan norma-norma sosial dan norma keagamaan secara ketat. Mereka mendapatkan bekal pengetahuan umum di bangku kuliah dan mendapatkan pengetahuan moral keagamaan dari pesantren. Dengan demikian, mereka diharapkan menjadi sarjana yang bermoral baik dan utuh ketika terjun di masyarakat.

Mereka datang sejak masa penjajahan Belanda di Indonesia. Para etnis keturunan Tionghoa ini menjadi penguasa lahan ekonomi di Indonesia di mana hampir semua lahan ekonomi, sebelum tahun 1998, dikuasai oleh mereka. Dikarenakan kurang melebur dengan masyarakat asli pribumi Indonesia, akhirnya pada kerusuhan 1998 merekalah yang menjadi sasaran utama. Setelah itu, para imigran Tionghoa ini memahami pentingnya integrasi budaya. Sedangkan akulturasi yaitu penerimaan sebagian unsur-usur asing tanpa menghilangkan kebudayaan asli, misalnya, adat Sekaten yang merupakan percampuran antara budaya Islam dengan budaya Jawa di mana struktur dari keduanya masih dapat terlihat walaupun sudah bercampur. Lihat Tim Penyusun, Ensiklopedi Nasional Indonesia, Vol. 7 (Jakarta: PT Cipta Adi Pustaka, 1989), 189.

${ }^{14}$ Yayasan Tunas Bangsa, Labirnya Konsep Assimilasi (Jakarta: Gramedia, 1977), 14. 
Pembagian porsi materi pendidikan agama dan umum dalam persentase tertentu, seperti di jenjang Madrasah Ibtidaiyah sampai Madrasah Aliyah, menurut A.M. Saefuddin sebenarnya masih tetap mengandung pandangan yang sifatnya dikotomis. Perpaduan itu mestilah terjadi sebagai proses pelarutan, dan bukan sekadar proses pencampuran (dalam konteks tulisan ini adalah "islamisasi"). Jadi, yang dimaksud integrasi di sini bukan sekadar menggabungkan pengetahuan umum dan agama atau memberikan bekal norma keagamaan kepada calon sarjana seperti di atas. Integrasi di sini adalah upaya menghubungkan kembali sunnat Allâh (hukum alam) dengan alQur'ân, yang keduanya adalah sama-sama ayat Tuhan. Pengertian ini didasarkan atas pernyataan bahwa ayat-ayat Tuhan terdiri atas dua hal, yaitu ayat-ayat yang bersifat linguistik, verbal, dan menggunakan bahasa insani, yaitu al-Qur'ân, dan ayat-ayat yang bersifat non-verbal berupa gejala alam..$^{15}$

Dengan demikian, integrasi yang dimaksud di sini tidak jauh berbeda dari konsep Islamisasi ilmu pengetahun. Keduanya samasama berkaitan dengan ilmu dan agama, dan berusaha menemukan paradigma baru. Cara integrasi seperti ini nantinya akan dikembangkan dalam struktur keilmuan yang dibangun di Perguruan Tinggi Keagamaan Islam (PTKI).

\section{Dasar Pengembangan Keilmuan Islam Multidisipliner di UIN Maulana Malik Ibrahim dan UIN Sunan Ampel}

Sampai pada tahun 2016 telah ada 11 IAIN/STAIN yang beralih status menjadi Universitas Islam Negeri (UIN), dan masing-masing institusi Pendidikan Tinggi Islam (PTI) tersebut memiliki pola pengembangan keilmuan yang bervariasi, misalnya UIN Maulana Malik Ibrahim Malang dengan konsep "pohon ilmu" dan UIN Sunan Ampel Surabaya menggunakan konsep "integrated twin towers". Meski konsep pengembangan keilmuan berbeda, namun PTI tersebut memiliki kesamaan dalam memandang hubungan antara ilmu alam, ilmu sosial dan humanities yaitu keinginan untuk membangun ketiga bidang tersebut melalui proses sinergi, interkoneksi atau interrelasi. Menurut Nanat Fatah, dalam visi keilmuan Qur'ânîah dan Kawnîyah,

\footnotetext{
15 A. Khudori Soleh, "Pokok Pikiran tentang Paradigma Integrasi Ilmu dan Agama" dalam M. Lutfi Musthofa dan Helmi Syaifuddin (eds.), Intelektualisme Islam Melacak Akar-akar Integrasi Ilmu dan Agama (Malang: Lembaga Kajian al-Qur'an dan Sains UIN Malang, 2006), 231-232.
} 
tidak dikenal dikotomi ilmu umum dan ilmu agama. ${ }^{16}$ Hal inilah yang ingin dibangun oleh PTI tersebut, yaitu ilmu yang terintegrasi dan non-dikotomi. Tulisan ini mengambil contoh pola pengembangan keilmuan integratif di dua PTKIN terbesar di Jawa Timur, yaitu UIN Maulana Malik Ibrahim Malang dan UIN Sunan Ampel Surabaya.

Namun penulis ingin terlebih dahulu secara singkat memaparkan beberapa konsep tentang integrasi ilmu dan agama yang dapat digunakan untuk mengembangkan keilmuan Islam multidisipliner di UIN, sebagai berikut: pertama, integrasi teologis yang dikembangkan Ian Barbour. Konsep ini berusaha mencari implikasi teologis atas berbagai teori ilmiah mutakhir, kemudian satu teologi baru dibangun dengan memperhatikan juga teologi tradisional sebagai salah satu sumber. Pandangan konseptual teologi dapat berubah atas nama "belajar dari ilmu". ${ }^{17}$ Teori-teori ilmiah dapat memberikan dampak kuat bagi perumusan doktrin-doktrin tertentu terutama tentang penciptaan dan sifat manusia. Dalam hal ini, istilah yang digunakan Barbour adalah theology of nature, untuk membedakannya dengan istilah natural theology, bahwa klaim eksistensi Tuhan dapat disimpulkan oleh bukti tentang desain alam. Selain dua model integrasi tersebut, Barbour juga mendukung konsep integrasi sintesis sistematis, bahwa ilmu dan agama memberikan kontribusi pada pengembangan metafisika inklusif. ${ }^{18}$

Akan tetapi, pandangan theology of nature Barbour mendapat kritik dari Huston Smith dan Sayyed Hossein Nasr, karena apabila teologi setiap saat berubah karena berinteraksi atau belajar dari ilmu, maka akan menimbulkan kesan bahwa teologi berada di bawah ilmu. Sebagai pendukung filsafat perenial, dua tokoh ini berpandangan bahwa teologi dalam konsep esoterisnya memiliki kebenaran yang perenial (abadi). Teologi hendaknya menjadi tolok ukur bagi teoriteori ilmiah, dan bukan sebaliknya. ${ }^{19}$

Kedua, agama sebagai konfirmasi ilmu yang dikemukakan oleh John F. Haught. Integrasi yang diinginkan oleh Haught tidak hanya

16 Baca Nanat Fatah Natsir (ed.), Pandangan Keilmuan UIN: Wabyu Memandu Ilmu (Bandung: Gunung Jati Press, 2008).

${ }^{17}$ Ian G. Barbour, Juru Bicara Tuhan: Antara Sains dan Agama, terj. E.R. Muhammad (Bandung: Mizan, 2002), 82-83.

18 Ibid., 95.

19 Zainal Abidin Bagir, "Bagaimana Mengintegrasikan Ilmu dan Agama?" dalam Jarot Wahyudi (ed.), Integrasi Ilmu dan Agama: Interpretasi dan Aksi (Yogyakarta: MYIA-CRCS dan Suka Press, 2005), 21. 
meleburkan ilmu dan agama, serta tidak hanya bertujuan untuk menghindari konflik, tetapi menempatkan agama sebagai pendukung seluruh kegiatan ilmiah. Menjawab berbagai pandangan yang menuduh bahwa ilmulah yang menyebabkan berbagai persoalan dalam kehidupan ini, misalnya kerusakan lingkungan, Haught justru menyatakan bahwa agama memberikan "konfirmasi" terhadap perkembangan ilmu. Meskipun agama memberikan konfirmasi, agama tidak boleh mencampuri bidang nyata karya ilmu karena agama tidak dapat menambahkan apapun pada daftar penemuan ilmu. Agama tidak memberikan informasi kepada ilmuwan seperti halnya informasi yang dapat dikumpulkan oleh ilmu itu sendiri. ${ }^{20}$

Meski begitu, konsep integrasi yang dikemukakan Haught terkesan belum optimal. Hal ini karena dalam al-Qur'ân banyak ayat yang mendasari dan menstimulasi penemuan ilmiah, bahkan menjadi paradigma bagi pengembangan ilmu, seperti:

1. Beberapa ayat yang memberikan informasi terkait dengan ilmu kesehatan antara lain:

a. Surat al-Nahl [16]: 68 dan 69 mengenai kehidupan lebah yang menghasilkan madu dan sari buah-buahan yang dapat dijadikan obat bagi manusia.

b. Surat al-Baqarah [2]: 233 mengenai gizi yang terbaik untuk bayi, yaitu anjuran menyempurnakan penyusuan bayi hingga dua tahun.

2. Ayat yang memberikan informasi tentang penciptaan alam semesta yaitu bahwa alam semesta diciptakan oleh Allah dengan sistem evolusi atau bertahap, misalnya Q.S. al-Sajdah [32]: 4. Ayat tersebut sebenarnya menunjukkan bahwa tidak ada pertentangan antara paham kreasionisme dan evolusionisme.

Ketiga, Islamisasi ilmu yang dikembangkan oleh Muhammad Naquib al-Attas dan Isma'il Raji al-Faruqi. Islamisasi ilmu menurut alAttas dimaksudkan sebagai upaya dewesternisasi ilmu yang telah menyusup dalam seluruh aspek keilmuan. Ilmu harus dibersihkan dari aspek sekularisme, dengan meletakkan kembali otoritas wahyu dan intuisi. $^{21}$

\footnotetext{
${ }^{20}$ John F. Haught, Perjumpaan Sains dan Agama: Dari Konflik ke Dialog, terj. Fransiskus Borgias (Bandung: Mizan, 2004), 28.

21 Syed Muhammad Naquib Al-Attas, Islam dan Sekularisme (Bandung: Pustaka, 1981), 148.
} 
Islamisasi ilmu al-Attas dalam konteks integrasi dapat dikatakan sebagai "integrasi monistik". Ia menegasikan dualisme ilmu antara ilmu fard 'ayn dan fard kifâyah, ilmu 'aqlîyah dan ilmu naqlìyah sebagaimana diungkapkan oleh al-Ghazâlî. Setiap ilmu mempunyai status ontologis yang sama, yang membedakan adalah pada hierarki ilmu, yaitu tingkat kebenarannya, misalnya naqliyah memiliki tingkat kebenaran lebih tinggi daripada ilmu 'aqlîyah. ${ }^{22}$

Sedangkan menurut al-Faruqi, islamisasi ilmu dimaknai sebagai upaya pengintegrasian disiplin ilmu-ilmu modern dengan khazanah peradaban Islam. Langkah pertama dari upaya ini adalah dengan menguasai seluruh disiplin ilmu modern, memahaminya secara menyeluruh, dan mencapai tingkatan tertinggi yang ditawarkannya. Setelah prasarat ini dipenuhi tahap berikutnya adalah melakukan eliminasi, mengubah, menginterpretasikan ulang dan mengadaptasikan komponen-komponen dengan pandangan dunia Islam dan nilai-nilai yang tercakup di dalamnya. ${ }^{23}$

Pemikiran al-Attas dan al-Faruqi tentang islamisasi ilmu ada sedikit perbedaan. Al-Faruqi tampaknya lebih bisa menerima konstruk ilmu pengetahuan modern, yang penting adalah penguasaan terhadap prinsip-prinsip Islam sehingga sarjana Muslim dapat membaca dan menafsirkan konstruk ilmu pengetahuan modern tersebut dengan cara yang berbeda. Sementara al-Attas lebih menekankan pada autentisitas yang digali dari tradisi lokal. Dalam pandangan al-Attas, peradaban Islam klasik sudah cukup lama berinteraksi dengan peradaban lain, sehingga umat Islam sudah memiliki kapasitas untuk mengembangkan bangunan ilmu pengetahuan sendiri.

Sardar menolak pandangan al-Attas dan al-Faruqi bahwa salah satu tujuan program Islamisasi ilmu pengetahuan adalah untuk menetapkan relevansi antara Islam dengan setiap bidang ilmu pengetahuan modern. Menurutnya, bukan Islam yang perlu direlevankan dengan pengetahuan modern, melainkan ilmu pengetahuan modern yang harus relevan dengan Islam. ${ }^{24}$

Keempat, pengilmuan Islam yang dikemukakan Kuntowijoyo. Model ini membalik konsep Islamisasi ilmu yang merupakan gerakan dari konteks ke teks menjadi gerakan dari teks menuju ke konteks,

22 Arqom Kuswanjono, Integrasi Ilmu dan Agama Perspektif Filsafat Mulla Sadra (Yogyakarta: Lima, 2010), 74.

23 al-Faruqi, Islamisasi Pengetabuan, 98-115.

${ }^{24}$ Ziauddin Sardar, Islamic Future (Malaysia: Selangor Darul Ehsan, 1988), 101. 
maksudnya teks al-Qur'ân dan Ḥadîth dijadikan sebagai paradigma bagi pengembangan ilmu. Menurutnya, ada dua metodologi yang dapat dipakai dalam proses pengilmuan Islam, yaitu integralisasi dan objektivikasi. Integralisasi adalah pengintegrasian kekayaan keilmuan manusia dengan wahyu (petunjuk Allah dalam al-Qur'ân serta pelaksanaannya dalam sunnah Nabi). Sedangkan objektivikasi adalah menjadikan pengilmuan Islam sebagai rahmat untuk semua orang. ${ }^{25}$

Kuntowijoyo menggambarkan alur pertumbuhan ilmu-ilmu integralistik sebagai berikut:

Agama $\rightarrow$ Teoantroposentrisme $\rightarrow$ Dediferensiasi $\rightarrow$ Ilmu

Penjelasan terhadap bagan di atas adalah:

Integralistik

1. Agama. Agama Islam, yang seluruh ajarannya bersumber dari alQur'ân, merupakan wahyu Tuhan yang mengatur hubungan manusia dengan Tuhan, diri sendiri, lingkungan (fisik, sosial, budaya). Al-Qur'an merupakan petunjuk etika, kebijaksanaan dan, dalam konteks ini, dapat dijadikan sebagai grand theory. Wahyu tidak pernah mengklaim sebagai ilmu qua ilmu.

2. Teoantroposentrisme. Agama memang mengklaim sebagai sumber kebenaran, etika, hukum, kebijaksanaan. Agama tidak pernah menjadikan wahyu Tuhan sebagai satu-satunya sumber pengetahuan dan melupakan kecerdasan manusia, atau sebaliknya menganggap pikiran manusia sebagai satu-satuya sumber pengetahuan dan melupakan Tuhan. Jadi sumber pengetahuan ada dua macam, yaitu yang berasal dari Tuhan dan yang berasal dari manusia.

3. Dediferensiasi. Peradaban yang disebut Pascamodern/Post-modern perlu ada perubahan. Perubahan itu adalah dediferensiasi. Kalau diferensiasi menghendaki pemisahan antara agama dan sektorsektor kehidupan lain, maka dediferensiasi adalah penyatuan kembali agama dengan sektor-sektor kehidupan lain, termasuk agama dan ilmu.

4. Ilmu integralistik. Ilmu yang menyatukan wahyu Tuhan dan temuan pikiran manusia. Ilmu-ilmu integralistik tidak akan mengucilkan Tuhan (sekularisme) atau mengucilkan manusia. Diharapkan

25 Kuntowijoyo, Islam sebagai Ilmu: Epistemologi, Metodologi, dan Etika (Yogyakarta: Tiara Wacana, 2007), 49. 
integralisme akan sekaligus menyelesaikan konflik antara sekularisme ekstrem dan agama-agama radikal dalam banyak sektor. ${ }^{26}$

Sementara itu, M. Amin Abdullah menawarkan konsep "jaringjaring laba-laba" keilmuan teoantroposentris-integralistik. Dalam hal ini, Abdullah ingin menunjukkan dua hal, yaitu: pertama, idealitas yang ingin dicapai dari teoantroposentris-integralistik yaitu penyatuan seluruh ilmu yang ada di dunia ini. Kedua, kondisi riil aktivitas keilmuan dari pendidikan agama di IAIN dan STAIN.

Kenyataannya, pendidikan agama hanya terfokus pada lingkaran ke-1 (al-Qur'ân dan Sunnah) dan lingkaran ke-2 (Kalam, Filsafat, Tasawuf, Hadith, Tarikh, Fiqh, Tafsir, Lughab), selain itu pendekatannya masih bersifat humaniora klasik. IAIN dan STAIN belum mampu memasuki diskusi ilmu-ilmu sosial humaniora kontemporer seperti tergambar dalam lingkaran ketiga (Antropologi, Sosiologi, Psikologi, Filsafat, dan lain-lain). Akibatnya, terjadi jurang yang tidak terjembatani antara ilmu-ilmu keislaman klasik dan ilmuilmu keislaman baru yang telah memanfaatkan analisis ilmu-ilmu sosial dan humaniora kontemporer. ${ }^{27}$

Berdasarkan pemaparan di atas, konsep integrasi ilmu agama dan ilmu umum dapat diringkas dalam tabel sebagai berikut:

\section{Tabel 2}

\section{Konsep Integrasi Ilmu Agama dan Ilmu Umum}

\begin{tabular}{|c|l|l|}
\hline No. & Tokoh Integrasi & Konsep Integrasi \\
\hline 1 & Ian Barbour & $\begin{array}{l}\text { Kembangkan integrasi teologis dengan } \\
\text { istilah theology of nature, bahwa klaim eksis- } \\
\text { tensi Tuhan dapat disimpulkan oleh bukti } \\
\text { tentang desain alam }\end{array}$ \\
\hline 2. & John F. Haught & $\begin{array}{l}\text { Agama sebagai konfirmasi ilmu (agama } \\
\text { sebagai pendukung seluruh upaya kegiatan } \\
\text { ilmiah) }\end{array}$ \\
\hline 3. & $\begin{array}{l}\text { Naquib al-Attas dan } \\
\text { Ismail Raji al-Faruqi }\end{array}$ & $\begin{array}{l}\text { Islamisasi ilmu (dari konteks ke teks) dalam } \\
\text { konteks integrasi dapat dikatakan "integrasi } \\
\text { monistik". Ia menegasi dualisme ilmu antara } \\
\text { ilmu fard ayn dan fard kifâyah, ilmu aqliyah } \\
\text { dan ilmu naqlyab sebagaimana diugkapkan }\end{array}$ \\
\hline
\end{tabular}

${ }^{26}$ Ibid., 51-54.

27 M. Amin Abdullah, "Etika Tauhidik sebagai Dasar Kesatuan Epistemologi Keilmuan Umum dan Agama: dari Paradigma Positivistik-Sekularistik ke Arah Teoantroposentrik-Integralistik", dalam Jarot Wahyudi (ed.), Menyatukan Kembali Ilmu-ilmu Agama dan Umum: Upaya mempertemukan Epistemologi Islam dan Umum (Yogyakarta: Sunan Kalijaga Press, 2003), 12-13. 


\begin{tabular}{|c|l|l|}
\hline & & al-Ghazâlî \\
\hline 4 & Kuntowijoyo & Pengilmuan Islam (dari teks ke konteks), \\
& & yaitu teks al-Qur'ân dan Hadîth dijadikan \\
& & sebagai paradigma bagi pengembangan ilmu. \\
& & $\begin{array}{l}\text { Ada dua metodologi yang dapat dipakai } \\
\text { dalam proses pengilmuan Islam, yaitu } \\
\text { integralisasi dan objektivikasi }\end{array}$ \\
\hline 5 & M. Amin Abdullah & $\begin{array}{l}\text { Jaring-jaring laba-laba keilmuan teoantropo- } \\
\text { sentris-integralistik }\end{array}$ \\
\hline
\end{tabular}

Selanjutnya, ada beberapa model integrasi ilmu dan agama yang dapat dijadikan panduan dalam mengembangkan keilmuan Islam multidisipiler. Menurut Armahedi Mahzar, model-model itu dapat diklasifikasikan dengan menghitung jumlah konsep dasar yang menjadi komponen utama model itu, yaitu model monadik, diadik, triadik, dan integralisme Islam. ${ }^{28}$

Pertama, model monadik populer di kalangan fundamentalis, religius, ataupun sekuler. Yang religius menyatakan agama adalah keseluruhan yang mengandung semua cabang kebudayaan. Sedangkan yang sekuler menganggap agama sebagai salah satu cabang kebudayaan. Dalam fundamentalisme religius, agama dianggap sebagai satu-satunya kebenaran dan sains hanya salah satu cabang kebudayaan, sedangkan dalam fundamentalisme sekuler kebudayaan adalah ekspresi manusia dalam mewujudkan kehidupan yang berdasarkan sains sebagai satu-satunya kebenaran. ${ }^{29}$

Dengan model monadik totalistik seperti ini tak mungkin terjadi koeksistensi antara agama dan sains, karena keduanya menegasikan eksistensi atau kebenaran yang lainnya. Maka hubungan antara kedua sudut pandang ini, tidak bisa tidak adalah konflik seperti yang dipetakan Ian Barbour atau John F. Haught mengenai hubungan antara sains dan agama. Tampaknya pendekatan totalistik seperti ini sulit untuk digunakan sebagai landasan integrasi sains dan agama di lembaga-lembaga pendidikan, dari TK hingga perguruan tinggi.

Kedua, model diadik. Model ini memiliki beberapa varian. Pertama dikatakan bahwa sains dan agama adalah dua kebenaran yang setara. Sains membicarakan fakta alamiah, sedangkan agama membicarakan

\footnotetext{
28 Armahedi Mahzar, "Integrasi Sains dan Agama: Model dan Metodologi" dalam Jarot Wahyudi (ed.), Integrasi Ilmu dan Agama: Interpretasi dan Aksi (Yogyakarta: MYIA-CRCS dan Suka Press, 2005), 94-106.

${ }_{29}$ Dalam bentuknya yang postmodernis, sains pun menjadi relatif seperti halnya agama.
} 
nilai ilahiah..$^{30}$ Barangakali ujaran Einstein science without religion is limb, religion without science is blind, yang sangat populer di kalangan dai Islam pada tahun 1960-an, merumuskan wawasan ini secara jelas. Dalam tipologi Barbour, model ini identik dengan relasi independensi. Dalam tipologi Haught, ini bisa disebut hubungan kontras. Pandangan inilah yang dianut negara Indonesia yang mengajarkan agama sebagai mata pelajaran atau mata kuliah terpisah di sekolah dan perguruan tinggi.

Varian kedua dari model diadik ini, sains dan agama adalah sebuah kesatuan yang tak terpisahkan. Barangkali, ini dapat dipahami dengan menyimak pandangan Fritjof Capra: "Sains tak membutuhkan mistisisme dan mistisisme tak membutuhkan sains. Akan tetapi, manusia membutuhkan keduanya." Sedangkan varian ketiga berpendapat bahwa antara ilmu dan agama memiliki kesamaan. Kesamaan itulah yang bisa dijadikan bahan integrasi keduanya.

Ketiga, model triadik sebagai sebuah koreksi terhadap model diadik independen. Dalam model triadik ada unsur ketiga yang menjembatani sains dan agama. Jembatan itu adalah filsafat. Model ini diajukan oleh kaum teosofis yang bersemboyan There is no religion higher than Truth. Kebenaran atau "Truth" adalah kesamaan antara sains, filsafat, dan agama.

Tampaknya model ini merupakan perluasan saja dari model diadik komplementer dengan memasukkan filsafat sebagai komponen ketiga yang letaknya di antara sains dan agama. Model triadik komplementer ini mungkin dapat dimodivikasi dengan menggantikan filsafat dengan humaniora atau ilmu-ilmu kebudayaan. Dengan demikian, kebudayaan yang menjambatani sains dan agama. Jadi dalam model ini, ilmu-ilmu kealaman dan ilmu-ilmu keagamaan dijembatani oleh humoniora dan ilmu-ilmu kebudayaan.

Keempat, model pentadik integralisme monistik Islam adalah sebuah paradigma univikasi bagi ilmu-ilmu kealaman dan ilmu-ilmu keagamaan. Akan tetapi, paradigma univikasi bukan hanya menyatukan ilmu kealaman dan ilmu keagamaan, melainkan juga merupakan paradigma ilmu-ilmu kemasyarakatan dan kemanusiaan.

Memahami arti penting dari konsep integralisme monistik Islam, Barizi menyarankan Islam sebagai 'paradigma' dalam berbagai kajian ilmu pengetahuan. Sebagai sebuah paradigma, Islam (dengan alQur'ân dan Sunnah) adalah sumber rujukan bagi setiap kerja ilmu.

\footnotetext{
${ }^{30}$ Pandangan ini berakar pada pemisahan antara fakta dan nilai seperti yang diajukan pertama kalinya oleh Immanuel Kant pada abad XIX.
} 
Tentu, melalui pemahaman seperti ini ayat-ayat al-Qur'ân dan Sunnah yang berkaitan dengan ilmu meniscayakan untuk dielaborasi secara saintifik sesuai kebutuhan kerja ilmiah yang dibangunnya. Di sini berarti Islam tidak sekadar menjadi perspektif atau sebagai pelengkap dari kajian ilmiah yang ada, dan apalagi kajian yang terpisah dari sains. Tetapi, justru Islam harus menjadi 'pengawal' dari setiap kerja sains oleh setiap para ilmuan (dosen). ${ }^{31}$

Beberapa gagasan tentang integrasi ilmu dan agama di atas, dapat dijadikan dasar pengembangan keilmuan Islam multidisipliner di UIN. Sebagai contoh adalah struktur keilmuan UIN Maulana Malik Ibrahim Malang yang dibangun berdasarkan prinsip universalitas ajaran Islam yang digambarkan sebagai pohon ilmu yang rindang dan kokoh.

Gagasan Imam Suprayogo tentang "Pohon Ilmu" yang dijadikan sebagai blue print pengembangan ilmu di UIN Maulana Malik Ibrahim Malang, memang ada sedikit perdebatan pada tataran epistemologinya. Menurut Muhaimin, sumber ilmu pengetahuan itu pada dasarnya datangnya dari Allah. Allah menciptakan alam semesta (ayat-ayat kawniyah) dan al-Qur'ân (ayat-ayat qawlìyah). Oleh karenanya kedua sumber tersebut saling menjelaskan dan tidak bertentangan terhadap berbagai ilmu pengetahuan tentang hakikat kebenaran. Selama ini banyak orang berfikir bahwa salah satu dari keduanya berada di sayap kanan sementara satu lainnya di kiri (dikotomik).

Dalam mengkaji ilmu Islam, menurut Fazlur Rahman yang dikutip Hamdi, ${ }^{32}$ sebaiknya harus dibedakan antara Islam sebagai objek kajian keilmuan dan Islam sebagai landasan etis. Sebagai objek kajian keilmuan, Islam harus tunduk dan patuh terhadap prosedur-prosedur keilmuan. Sebagai contoh, al-Qur'ân sebagai teks, maka ia bisa dikaji oleh siapa saja, tidak peduli apakah orang itu mempercayai al-Qur'ân sebagai wahyu yang datang dari Tuhan atau tidak. Inilah yang dikatakan oleh Fazlur Rahman bahwa orang non-Muslim pun bisa mengkaji al-Qur'ân dan hasilnya memiliki derajat yang sama dengan tafsir yang disusun oleh seorang Muslim. Kedua tafsir tersebut samasama memiliki derajat relatif dalam perspektif ilmu. Oleh sebab itu, al-

31 Barizi, "Penguatan dan Pengembangan Integrasi Sains dan Islam", makalah disampaikan pada workshop pada Fakultas Sains dan Teknologi UIN Maulana Malik Ibrahim Malang, 3-4 Februari 2010 di Hotel Wisata Tidar Malang.

32 A. Zainul Hamdi, "Menilai Ulang Gagasan Integrasi Ilmu Pengetahuan sebagai Blue Print Pengembangan Keilmuan UIN”, dalam Zainal Abidin Bagir (ed.), Integrasi Ilmu dan Agama: Interpretasi dan Aksi (Yogyakarta: MYIA-CRCS dan Suka Press, 2005), 183-185. 
Qur'ân sebagai teks harus terbuka untuk dikaji melalui teori-teori teks sebagaimana teori-teori tersebut digunakan untuk mengkaji teks-teks sekuler non-ilahi. Di sisi lain, Islam sebagai landasan etis, ia menjadi pedoman pemeluknya untuk bertindak arif dalam hidup, seperti sikap amanah, adil, tasâmuh, tawassut, tawâzun, dan lain sebagainya. Hal ini pun dalam operasionalisasinya harus tunduk pada ruang dan waktu yang melingkupinya. Namun, bila Islam dipandang sebagai landasan etis, seharusnya dalam proses pembelajaran pendidikan agama bukan hanya dijadikan sebagai "pelajaran atau pengetahuan" tentang ilmu agama, tetapi seharusnya dilakukan dengan cara penanaman nilai-nilai luhur dan bentuk keteladanan dan pengalaman yang akan lebih efektif daripada internalisasi nilai melalui ucapan dan ceramah seperti yang selama ini terjadi di perguruan tinggi Islam.

Menurut Imam Suprayogo, ada dua tawaran terkait dengan peletakan al-Qur'ân sebagai sumber ilmu pengetahuan. Pertama, meletakkan al-Qurân sebagai konsep dasar atau inspirasi yang kemudian dikembangan melalui berbagai riset ilmiah. Kedua, meletakkan al-Qur'ân (fenomena naqlîyah) dan alam (fenomena kawnŷah) menjadi dua sumber yang setara bagi bangunan ilmu pengetahuan. ${ }^{33}$ Pada tawaran pertama mucul sebuah pertanyaan, apa yang dimaksud dengan al-Qur'ân sebagai sumber ilmu pengetahun? Kalau yang dimaksud adalah al-Qur'ân sebagai salah satu makhluk Tuhan yang dapat dijadikan sebagai salah satu sumber ilmu pengetahuan maka dapat dibenarkan, karena Allah juga menciptakan fenomena lain yang bersifat kawniyah (alam semesta) dan fenomena nafsîyah (manusia) yang juga memiliki kontribusi besar sebagai sumber ilmu pengetahuan, teknologi, dan seni.

Bagaimana bila al-Qur'ân dijadikan sebagai sumber inspirasi? Pertanyaan berikutnya adalah apakah teori yang dihasilkan oleh seorang ilmuwan yang berasal dari inspirasi/renungan tentang fenomena di sekitarnya tidak atau kurang Islami dibandingkan dengan teori seorang ilmuwan yang mendapat inspirasi langsung dari alQur'ân? Kalau dikatakan "ya”, pertanyaan berikutnya adalah dengan ukuran apa sebuah teori dikatakan Islami dan tidak Islami? Apakah sebuah teori Islami semata-mata didasarkan atas sumber inspirasinya ataukah kejujuran ilmiah yang diemban oleh seorang ilmuwan sekalipun dia tidak memperoleh inspirasinya dari al-Qur'ân, atau

33 Imam Suprayogo, Universitas Unggul: Refleksi Pemikiran Pengembangan Kelembagaan dan Reformasi Paradigma Keilmuan Islam (Malang: UIN Press, 2009), 45. 
bahkan mungkin dia tidak bisa membaca al-Qur'ân? Oleh sebab itu, ada sekian banyak problem epistemologis yang terkait dengan dua hal tersebut. Cara pandang yang berbeda akan menghasilkan rumusan pengetahuan yang berbeda, baik mengenai alam maupun al-Qur'ân. ${ }^{34}$

Realitas keilmuan seperti ini semakin memperlihatkan bahwa aktivitas ilmiah adalah aktivitas ilmiah, dia tidak bisa disekat berdasarkan keyakinan-keyakinan religius apapun. Misalnya, kita menggagas suatu teori ilmiah yang dianggap berdasarkan al-Qur'ân dan Hadîth, maka itu hanyalah salah satu varian dari sekian banyak pandangan yang berbeda-beda. Sebuah ayat tidak bisa memberi privileges apapun terhadap teori kita atas teori lain yang tidak ada ayatnya. Bahkan-menurut Hamdi-ketika ada dua orang ilmuwan yang mendapatkan inspirasinya dari al-Quran, bisa jadi dia akan mengkonstruksi teori yang berbeda. Hal ini karena inspirasi Qur'ânî lahir bukan sebagai sesuatu yang given, tapi disebabkan oleh cara seseorang memandang dan membaca al-Quran. ${ }^{35}$

Berdasarkan pemikiran tersebut, konsep integrasi ilmu umum dan ilmu agama yang digunakan sebagai blue print pengembangan keilmuan di UIN Malang sebenarnya merupakan upaya untuk menghilangkan dikotomi keilmuan tersebut. ${ }^{36}$ Dengan demikian, Islamic knowledge (alulùm al-Islâmîab) yang dikembangkan oleh UIN Maulana Malik Ibrahim adalah ilmu pengetahuan yang dibangun berdasarkan ajaran Islam yakni al-Qur'ân dan Hadîth, sekaligus pengetahuan yang sama dibangun berdasarkan hasil observasi, eksperimentasi, dan penalaran logis. Jika al-Qur'ân dan Ḥadîth diletakkan pada posisi sumber ilmu, maka tidak akan terjadi cara pandang ilmu yang dikotomik yang justru merendahkan posisi Kitab Suci. Sudah barang tentu sebagai konsekuensi al-Qurân yang bersifat universal masih diperlukan sumber pengetahuan lain yang bersifat teknis, yaitu ilmu pengetahuan yang diperoleh melalui observasi, eksperimen, dan penalaran logis.

Berdasarkan pola pengembangan keilmuan tersebut, maka untuk memperkuat sistem kelembagaan, UIN Maulana Malik Ibrahim membentuk sembilan Arkân al-Jâmi'ah (rukun perguruan tinggi)

\footnotetext{
${ }^{34}$ Hamdi, "Menilai Gagasan Ulang Islamisasi Ilmu”, 186-188.

35 Ibid.

36 Mengenai konsep integrasi ilmu umum dan ilmu agama masing-masing UIN di Indonesia memiliki konsep keilmuan yang berbeda tetapi dengan tujuan yang sama; UIN Syarif Hidayatullah Jakarta dengan konsep "Integrasi Ilmu", UIN Sunan Kalijaga Yogyakarta dengan "Jaring Laba-Laba", UIN Bandung dengan konsep "Wahyu Memandu Ilmu".
} 
sebagai pilar pengembangan, yaitu: a). SDM yang unggul; b). Masjid; c). Ma'bad sebagai pengembangan spiritual, intelektual, dan jiwa profesional; d). Perpustakaan; e). Laboratorium sebagai wahana penelitian; f). Tempat-tempat pertemuan ilmiah; g). Perkantoran sebagai pusat pelayanan akademik; h). Pusat-pusat pengembangan seni dan olahraga; dan i). Sumber pendanaan yang luas dan kuat. ${ }^{37}$

Tidak jauh berbeda dari pola pengembangan keilmuan di UIN Maulana Malik Ibrahim, UIN Sunan Ampel juga mengembangkan keilmuan Islam multidispliner dengan paradigma Integrated TwinsTowers. Nur Syam ${ }^{38}$ menjelaskan bahwa konsep "menara kembar" di dalam konsepsi pengembangan ilmu keislaman multidisipliner yang dimaksudkan adalah membangun struktur keilmuan yaitu ilmu keagamaan dan ilmu sosial/humaniora di satu sisi serta ilmu alam di sisi lain secara memadai dan wajar. Keduanya memiliki kewibawaan yang sama, sehingga antara satu dengan lainnya tidak terdapat superiorioritas maupun inferioritas. Ilmu keislaman berkembang dalam kapasitas dan kemungkinan perkembangannya, demikian pula ilmu lainnya juga berkembang dalam rentangan dan kapasitasnya. Ilmu keislaman bagaikan sebuah menara yang satu dan ilmu lainnya seperti menara satunya lagi. Keduanya bertemu dalam puncak yang saling menyapa, yang dikenal dengan konsep ilmu keislaman multidisipliner. Menara yang satu menjadi subject matter dan lainnya sebagai pendekatan.

Konsep Integrated Twins-Towers bila dirumuskan secara naratif, maka gambarannya yaitu, fondasi keilmuannya ialah al-Qur'ân dan Hadîth di mana di satu sisi menara terdiri dari ilmu keislaman murni dan terapan (tafsir, hadîth, ilmu fiqh, ilmu kalam, tasawuf, ilmu dakwah, ilmu tarbiyah dan sebagainya), sedangkan di satu menara lainnya adalah ilmu alam, ilmu sosial dan humaniora (ilmu kimia, fisika, sosiologi, antropologi, politik, psikologi, sejarah, filsafat dan sebagainya). Selanjutnya, di puncak kedua menara terdapat lengkung yang menghubungkan antara menara satu dengan lainnya yang menyimbolkan pertautan antara dua disiplin keilmuan, sehingga

\footnotetext{
37 Tim Penyusun, 4 Tahun Universitas Islam Negeri Malang (Malang: UIN Press, 2009), 90.

38 Nur Syam, "Membangun Keilmuan Islam Multidisipliner: Memahami Proses Saling Menyapa Ilmu Agama dan Umum" dalam Nur Syam (ed.), Integrated Twin Towers: Arah Pengembangan Islamic Studies Multidisipliner (Surabaya: Sunan Ampel Press, 2010), 12-14.
} 
terdapatlah disiplin sosiologi agama, filsafat agama, antropologi agama, ekonomi Islam, politik Islam, dan sebagainya.

Bangunan struktur keilmuan tersebut harus diletakkan di atas fondasi al-Qur'ân dan Hadîth, dikarenakan yang akan dibangun adalah ilmu sosial profetik, ilmu alam profetik, serta culture dan humaniora profetik menurut pandangan ilmuwan yang mengembangkan ilmuilmu trans-teoretik, yaitu teori yang tidak hanya digunakan semata untuk teori tetapi teori untuk kemungkinan pengembangan masyarakat. Dengan demikian, setiap teori yang dihasilkan oleh ilmuwan Islam hakikatnya adalah bertujuan untuk meningkatkan taraf kehidupan masyarakat lebih baik.

Pembidangan ilmu-ilmu keislaman juga diusahakan melalui pengkategorian apa yang menjadi sasaran kajiannya, maka ditemukanlah pembidangan seperti Ilmu al-Qur'ân yang sasaran kajiannya adalah al-Qur'ân, Ilmu Hạdîth yang menempatkan hadîthhadîth Nabi sebagai sasaran kajiannya, Ilmu Akidah yang memiliki sasaran kajian berupa dimensi-dimensi keyakinan terhadap Tuhan dan hal-hal yang terkait dengannya, Ilmu Dakwah yang memiliki sasaran kajian terkait dengan penyebaran ajaran Islam, Ilmu Tarbiyah yang memiliki sasaran kajian berupa pendidikan Islam, Ilmu Syariah yang memiliki sasaran kajian berupa hukum Islam dan implikasinya, Ekonomi Islam yang memiliki sasaran kajian berupa praktik ekonomi dan implikasinya, Ilmu Filsafat yang mengkaji tentang berbagai corak dan ragam pemikiran mendalam tentang gejala-gejala alam, sosial dan humaniora, Ilmu Tasawuf yang mengkaji tentang dimensi mendalam (esoteris) Islam, Ilmu Sejarah yang mengkaji tentang rentang perjalanan manusia dan masyarakat dalam kaitannya dengan agama, sosial, budaya, politik, hukum, ekonomi dan sebagainya. Terdapat juga ilmu-ilmu sosial-keislaman yang mengkaji tentang interaksi antara individu dan masyarakat dalam kaitannya dengan agama, sosial, budaya, politik dan sebagainya serta sains Islam yang mengkaji tentang gejala-gejala alam dalam kaitannya dengan konsepsi-konsepsi Islam. Untuk membedakan satu disiplin dengan lainnya adalah melalui pengalokasian objek formal yang masing-masing berbeda, misalnya sejarah peradaban Islam akan berbeda dari sejarah hukum Islam, sosiologi agama akan berbeda dari psikologi agama, dan sebagainya.

Berdasarkan uraian di atas, arah pengembangan ilmu-ilmu keislaman multidisipliner di UIN Sunan Ampel diusahakan mengikuti alur sasaran kajian dan pendekatan sekaligus. Artinya, pengembangan 
tersebut diusahakan dengan menggunakan dua cara pembidangan ilmu-ilmu, yaitu melihat sasaran kajian dan pendekatan. Pada akhirnya akan ditemui pola pengembangan yang merupakan penggabungan ilmu, yang satu dijadikan sebagai sasaran kajian dan lainnya sebagai pendekatan. Misalnya, tafsir al-Qur'ân dan hermeneutika, maka yang dikaji adalah tafsir al-Qur'ân tetapi menggunakan pendekatan hermeneutika. Demikian pula tafsir al-Qur'ân dan fenomenologi, maka yang dikaji adalah ilmu tafsir tetapi menggunakan pendekatan fenomenologi. Demikian pula ilmu Hadîth ketika dipertemukan dengan pendekatan lainnya maka akan memunculkan syarah Hadîth dan budaya lokal, sharb Hadîth dan fenomenologi dan seterusnya. Ilmu Tarbiyah yang ditemukan dengan sosiologi maka akan memunculkan sosiologi pendidikan Islam, teknologi pendidikan Islam, politik pendidikan Islam dan sebagainya.

Pembidangan ilmu, dengan demikian, tidak hanya akan menghasilkan substansi keilmuan Islam akan tetapi juga akan menghasilkan variasi-variasi akademisi yang menjadi hasil pengembangan ilmu-ilmu keislaman dimaksud. Jadi, melalui pembidangan ilmu akan didapatkan dua keuntungan, yaitu variasi ilmu-ilmu keislaman dan variasi pakar ilmu keislaman. Sedangkan pada tataran operasional praktis, UIN Sunan Ampel mengembangkan tiga pilar program akademik, sebagai ciri khasnya yaitu: (1) penguatan ilmu-ilmu keislaman murni tapi langka; (2) integralisasi keilmuan keislaman pengembangan dengan keilmuan sosial-humaniora; dan (3) pembobotan keilmuan sains dan teknologi dengan keilmuan keislaman. Tiga hal ini disebut dengan "integrated twin towers with three pillars". ${ }^{39}$

Konsep integrasi keilmuan, baik di UIN Maulana Malik Ibrahim Malang maupun di UIN Sunan Ampel Surabaya, menegaskan Islam sebagai paradigma dalam berbagai kajian ilmu pengetahuan. Melalui pemahaman seperti ini ayat-ayat qawliyah yang berhubungan dengan ilmu pengetahuan meniscayakan untuk dielaborasi secara saintifik sesuai dengan kebutuhan kerja ilmiah yang dibangunnya. Seperti diungkapkan oleh Oesman Bakar bahwa al-Qur'ân bukanlah kitab sains, tapi ia memberikan pengetahuan tentang prinsip-prinsip sains yang selalu dikaitkannya dengan pengetahuan metafisik dan spiritual. ${ }^{40}$

39 Husniyatus Salamah Zainiyati, Desain Pengembangan Kurikulum Integratif IAIN Menuju UIN Sunan Ampel (Surabaya: IAIN Sunan Ampel Press, 2012), 125.

${ }^{40}$ Bakar, Taubid dan Sains, 151. 
Pendapat tersebut diikuti oleh Endang Saefuddin Anshari yang menyatakan bahwa al-Qur'ân tidak lain adalah pembukuan segenap alam semesta dalam satu al-Kitâb di mana keduanya saling menafsirkan. ${ }^{41}$

Dengan pengembangan paradigma integratif-multidisipliner di atas, ilmu-ilmu yang dikembangkan di PTKI merupakan upaya integrasi ilmu-ilmu keislaman dengan sains Barat; tidak hanya sekadar "menjajakan" sains Barat di lingkungan PTKI. Integrasi ilmu ini dilakukan dengan tidak saja membuka prodi-prodi baru di luar bidang ilmu-ilmu keislaman, akan tetapi juga menyelenggarakan pelembagaan integrasi ilmu itu melalui perubahan institusi Institut Agama Islam Negeri (IAIN) menjadi Universitas Islam Negeri (UIN).

Sesuai dengan kebutuhan pengembangan kelembagaan di UIN, maka pola pengembangan keilmuan multidisipliner di UIN, menurut Akh. Muzakki, harus dibangun dari kesadaran bahwa keberhasilan pendidikan yang diselenggarakan tidak saja dipengaruhi oleh pembelajaran di kampus akan tetapi pembelajaran lebih luas, yakni melalui interaksi kehidupan mahasiswanya dengan lingkungan di sekitarnya, baik langsung maupun tidak. Standar keberhasilan seperti ini memang juga berlaku di perguruan tinggi lainnya, namun tidak seberat yang harus ditunaikan oleh IAIN/UIN menyusul posisinya yang sudah dari awal dipersepsikan oleh masyarakat luas sebagai lembaga akademik dan lembaga dakwah. ${ }^{42}$

Hal tersebut sebagaimana diungkapkan oleh Azyumardi Azra bahwa pengembangan perguruan tinggi Islam pada mulanya didorong oleh beberapa tujuan, yaitu: (1) untuk melaksanakan pengkajian dan pengembangan ilmu-ilmu agama Islam pada tingkat yang lebih tinggi secara sistematis dan terarah; (2) untuk melaksanakan pengembangan dan peningkatan dakwah Islamiyah, dan (3) untuk melakukan reproduksi dan kaderisasi ulama dan fungsionaris keagamaan, baik pada kalangan birokrasi negara maupun swasta, serta lembagalembaga sosial, dakwah, pendidikan dan lain sebagainya. ${ }^{43}$ Jika dilihat dari kacamata historis ini, pesantren merupakan suatu yang signifikan untuk mewujudkan kaderisasi ulama di perguruan tinggi Islam.

\footnotetext{
${ }^{41}$ Anshari, Ilmu, Filsafat dan Agama, 176.

42 Akh. Muzakki, "Perspektif Pendidikan tentang Pengembangan Keilmuan Multidisipliner" dalam Nur Syam (ed.), Integrated Twin Towers: Arab Pengembangan Islamic Studies Multidisipliner (Surabaya: Sunan Ampel Press, 2010), 430-436.

${ }^{43}$ Azra, Pendidikan Islam: Tradisi dan Modernisasi, 170.
} 
Oleh karena itu, pengembangan keilmuan multidisipliner di UIN Sunan Ampel Surabaya maupun UIN Maulana Malik Ibrahim Malang di samping dilengkapi dengan perkuliahan reguler, sebagaimana perguruan tinggi lainnya, juga dengan perkuliahan non-reguler model pengasramaan pesantren. Kepentingan pengembangan keilmuan multidisipliner melalui skema perkuliahan reguler dan pengasramaan di atas adalah bersifat komplemen, yakni untuk membantu menjamin terselenggaranya kurikulum pembelajaran yang bergerak di dua paradigma besar, yaitu keilmuan agama dan umum, melalui proses integrasi. Tentu, integrasi di sini-sekali lagi—lebih dimaksudkan untuk menjamin satu disiplin keilmuan sebagai objek kajian dan lainnya sebagai pendekatan, sehingga proses pengembangan keilmuan Islam multidisipliner akan terealisasi.

\section{Penutup}

Pengembangan keilmuan Islam multidisipliner di UIN menekankan integrasi ilmu agama dan ilmu umum dalam kurikulum dan model pembelajaran yang dijalankan. Dengan demikian, Islamic knowledge (al-'ulum al-Islâmîyah) yang dikembangkan adalah ilmu pengetahuan yang dibangun berdasarkan ajaran Islam-sebagaimana tertuang dalam sumber ajarannya yang utama, yakni al-Qur'ân dan alSunnah—sekaligus pengetahuan yang sama dibangun berdasarkan hasil observasi, eksperimentasi, dan penalaran logis.

Sedangkan model integrasi keilmuannya dapat menggunakan model pentadik integralisme monistik Islam yaitu sebuah paradigma univikasi bagi ilmu-ilmu kealaman dan ilmu-ilmu keagamaan. Akan tetapi, paradigma univikasi itu bukan hanya menyatukan ilmu-ilmu kealaman dan ilmu-ilmu keagamaan, melainkan juga merupakan paradigma ilmu-ilmu kemasyarakatan dan kemanusiaan. Dalam hal ini, Islam tidak sekadar menjadi perspektif atau sebagai pelengkap dari kajian ilmiah yang ada, apalagi kajian yang terpisah dari sains, melainkan Islam justru harus menjadi "pengawal" dari setiap kerja sains oleh setiap para ilmuan (dosen). Di samping tercermin dalam aspek kurikulum, integrasi ilmu agama dan ilmu umum juga teraktualisir dalam model pembelajaran yang dikembangkan, di mana UIN seharusnya mengembangkan keterpaduan tradisi intelektual perguruan tinggi dan tradisi kearifan pesantren.

\section{Daftar Rujukan}

Abdullah, M. Amin. "Etika Tauhidik sebagai Dasar Kesatuan Epistemologi Keilmuan Umum dan Agama: dari Paradigma 
Positivistik-Sekularistik ke Arah Teoantroposentrik-Integralistik", dalam Jarot Wahyudi (ed.), Menyatukan Kembali Ilmu-ilmu Agama dan Umum: Upaya mempertemukan Epistemologi Islam dan Umum. Yogyakarta: Sunan Kalijaga Press, 2003.

-----. "UIN: Menuju Integrasi Ilmu dan Agama" dalam M. Zainuddin (ed.), Memadu Sains dan Agama Menuju Universitas Islam Masa Depan. Malang: Bayumedia Publishing, 2004.

Al-Attas, Syed Muhammad Naquib. Islam dan Sekularisme. Bandung: Pustaka, 1981.

al-Faruqi, Isma'il Raji. Islamisasi Pengetahuan, terj. Anas Mahyudin. Bandung: Pustaka, 1984.

Anshari, Endang Saifuddin. Ilmu, Filsafat, dan Agama. Surabaya: Bina Ilmu, 1987.

Azra, Azyumardi. Pendidikan Islam: Tradisi dan Modernisasi Menuju Milenium Baru. Jakarta: Logos Wacana Ilmu, 1999.

Bagir, Zainal Abidin. "Bagaimana Mengintegrasikan Ilmu dan Agama?" dalam Jarot Wahyudi (ed.), Integrasi Ilmu dan Agama: Interpretasi dan Aksi. Yogyakarta: MYIA-CRCS dan Suka Press, 2005.

Bakar, Oesman. Taubid dan Sains: Perspektif Islam tentang Agama dan Sains, terj. Yuliani Liputo dan M. S. Nasrulloh. Bandung: Pustaka Hidayah, 2008.

Bangsa, Yayasan Tunas. Labirnya Konsep Assimilasi. Jakarta: Gramedia, 1977.

Barbour, Ian G. Juru Bicara Tuhan: Antara Sains dan Agama, terj. E.R. Muhammad. Bandung: Mizan, 2002.

Barizi. "Penguatan dan Pengembangan Integrasi Sains dan Islam", makalah disampaikan pada workshop pada Fakultas Sains dan Teknologi UIN Maulana Malik Ibrahim Malang, 3-4 Februari 2010 di Hotel Wisata Tidar Malang.

Hamdi, A. Zainul. "Menilai Ulang Gagasan Integrasi Ilmu Pengetahuan sebagai Blue Print Pengembangan Keilmuan UIN", dalam Zainal Abidin Bagir (ed.), Integrasi Ilmu dan Agama: Interpretasi dan Aksi. Yogyakarta: MYIA-CRCS dan Suka Press, 2005.

Haught, John F. Perjumpaan Sains dan Agama: Dari Konflik ke Dialog, terj. Fransiskus Borgias. Bandung: Mizan, 2004.

Kuntowijoyo. Islam sebagai Ilmu: Epistemologi, Metodologi, dan Etika. Yogyakarta: Tiara Wacana, 2007. 
Kuswanjono, Arqom. Integrasi Ilmu dan Agama Perspektif Filsafat Mulla Sadra. Yogyakarta: Lima, 2010.

Mahzar, Armahedi. "Integrasi Sains dan Agama: Model dan Metodologi" dalam Jarot Wahyudi (ed.), Integrasi Ilmu dan Agama: Interpretasi dan Aksi. Yogyakarta: MYIA-CRCS dan Suka Press, 2005.

Muzakki, Akh. "Perspektif Pendidikan tentang Pengembangan Keilmuan Multidisipliner" dalam Nur Syam (ed.), Integrated Twin Towers: Arah Pengembangan Islamic Studies Multidisipliner. Surabaya: Sunan Ampel Press, 2010.

Nasution, Harun. Filsafat dan Mistisisme dalam Islam. Jakarta: Bulan Bintang, 1978.

Natsir, Nanat Fatah (ed.). Pandangan Keilmuan UIN: Wabyu Memandu Ilmu. Bandung: Gunung Jati Press, 2008.

Penyusun, Tim. 4 Tahun Universitas Islam Negeri Malang. Malang: UIN Press, 2009.

Penyusun, Tim. Ensiklopedi Nasional Indonesia, Vol. 7. Jakarta: PT Cipta Adi Pustaka, 1989.

Poerwadarminto, W.Y.S. Konsorsium Bahasa Indonesia. Jakarta: Balai Pustaka, 1986.

Sardar, Ziauddin. Islamic Future. Malaysia: Selangor Darul Ehsan, 1988.

Soleh, A. Khudori. "Pokok Pikiran tentang Paradigma Integrasi Ilmu dan Agama" dalam M. Lutfi Musthofa dan Helmi Syaifuddin (eds.), Intelektualisme Islam Melacak Akar-akar Integrasi Ilmu dan Agama. Malang: Lembaga Kajian al-Qur'an dan Sains UIN Malang, 2006.

Suprayogo, Imam. Universitas Unggul: Refleksi Pemikiran Pengembangan Kelembagaan dan Reformasi Paradigma Keilmuan Islam. Malang: UIN Press, 2009.

Syafei, Rachmat. "Integrasi Ilmu Agama dalam Sistem Kurikulum UIN" dalam Nanat Fatah Natsir (ed.), Pandangan Keilmuan UIN Wabyu Memandu Ilmu. Bandung: Gunung Jati Press, 2008.

Syam, Nur. "Membangun Keilmuan Islam Multidisipliner: Memahami Proses Saling Menyapa Ilmu Agama dan Umum" dalam Nur Syam (ed.), Integrated Twin Towers: Arah Pengembangan Islamic Studies Multidisipliner. Surabaya: Sunan Ampel Press, 2010.

Tafsir, Ahmad. Filsafat Pendidikan Islam: Integrasi Jasmani, Rohani, dan Kalbu Memanusiakan Manusia. Bandung: Remaja Rosdakarya, 2010. 
Husniyatus Salamah Zainiyati

Tafsir, Ahmad. Metodologi Pengajaran Agama Islam. Bandung: Remaja Rosdakarya, 1997.

Zainiyati, Husniyatus Salamah. Desain Pengembangan Kurikulum Integratif IAIN Menuju UIN Sunan Ampel. Surabaya: IAIN Sunan Ampel Press, 2012. 